\title{
Differential Responses of Hybrid Bluegrass and Kentucky Bluegrass to Drought and Heat Stress
}

\author{
Eleni M. Abraham \\ Laboratory of Range Science, Aristotle University of Thessaloniki, 54006 \\ Thessaloniki, Greece \\ William A. Meyer, Stacy A. Bonos, and Bingru Huang ${ }^{1}$ \\ Department of Plant Biology and Pathology, Rutgers University, Room 301 \\ Foran Hall, 59 Dudley Road, New Brunswick, NJ 08901
}

Additional index words. high temperature, Poa pratensis, Texas bluegrass, water stress

\begin{abstract}
This study was designed to investigate differential responses of hybrids from Texas bluegrass (Poa arachnifera Torr.) $\times$ Kentucky bluegrass (Poa pratensis L.) (KBG) and KBG genotypes to drought and heat stress. Plants of two hybrids, '845' and 'BDF', and two KBG genotypes ('Midnight' and ' $\mathrm{C}-74$ ') were grown under optimal temperature $\left(22 / 18{ }^{\circ} \mathrm{C}\right)$ and well-watered (control) or unwatered (drought) or superoptimal temperatures $\left(35 / 30{ }^{\circ} \mathrm{C}\right.$; heat stress) conditions for 35 days in growth chambers. Under optimal conditions, the two hybrids and two KBG genotypes were not significantly different in turf quality, leaf photochemical efficiency expressed as chlorophyll fluorescence ratio (Fv/Fm), leaf net photosynthetic rate (Pn), transpiration rate, water use efficiency (WUE), root dry matter, or root viability. The results suggest that the interspecific hybridization resulted in similar growth and physiological traits in the hybrid bluegrass as in a turf-type species under optimal temperature and irrigation regimes. Under drought stress, all these parameters were comparable to those for KBG 'Midnight', but significantly higher than the corresponding parameters for KBG ' $\mathrm{C}-74$ '. Under heat stress, both hybrids had significantly higher turf quality, Fv/Fm, Pn, transpiration rate, WUE, root dry weight in deeper soil depth $(40$ to $60 \mathrm{~cm})$, and root viability in the upper 40-cm layer compared with both KBG genotypes. These results suggested that hybrid bluegrass exhibited improvement in drought and heat tolerance, particularly in comparison with $\mathrm{KBG}$ ' $\mathrm{C}-74$ ', but to a great extent for heat tolerance. The maintenance of higher transpiration and photosynthesis, WUE, and root viability was associated with the improvement in heat tolerance in hybrid bluegrass.
\end{abstract}

Drought and heat stress are the two most detrimental environmental stresses for coolseason turfgrass growth in arid and warm climatic regions. Turfgrass plants develop various mechanisms in their adaptation to drought or heat stress, including changes in photosynthetic activities and regulation of water use and water uptake capacity (Beard, 1973; Fry and Huang, 2004). Generally, drought-resistant turfgrasses are able to maintain cellular hydration by closing stomata that limits transpirational water loss, increasing water uptake, and/or adjusting osmotically to maintain photosynthesis and other metabolic functions (Bonos and Murphy, 1999; Qian and Fry, 1997; White et al., 1992; Zhang and Schmidt, 1999). Heat tolerance in turfgrasses has been associated with the maintenance of transpiration and photosynthesis among various other mechanisms (Jiang and Huang, 2000).

Received for publication 14 Apr. 2008. Accepted for publication 2 Aug. 2008.

We thank Dr. Steve McCann and Emily Merewitz for critically reviewing the manuscript.

${ }^{1}$ To whom reprint requests should be addressed; e-mail huang@aesop.rutgers.edu
Kentucky bluegrass (Poa pratensis L.) (KBG) is a commonly used cool-season turfgrass species for home lawns, athletic fields, and golf courses. It forms an attractive turf when temperatures are optimal (18 to 24 ${ }^{\circ} \mathrm{C}$ ) and when supplied with adequate water, but quickly loses color, becomes thin, and goes dormant during extended heat and drought conditions (Meyer and Funk, 1989). Texas bluegrass (Poa arachnifera Torr.) (TBG) is a cool-season forage that is native to the southern United States and has good drought and heat resistance but is characterized by low turf quality and poor seed production (Gould, 1975). Interspecific hybridization between KBG and TBG has been used to develop hybrid bluegrass with improved turf quality and stress tolerance (Bonos et al., 2000; Read et al., 1999; Vinall and Hein, 1937). Some newly developed hybrids exhibited superior turf quality compared with Kentucky bluegrass genotypes under drought stress alone (Abraham et al., 2004) and under heat stress alone or in combination with drought stress compared with Kentucky bluegrass ('Apollo') and tall fescue (Festuca arundincea Schreb.) ('Dynasty') (Su et al., 2007). The mechanisms underlying the improvement in hybrid blue- grass over KBG are not well understood. Understanding differential physiological responses of hybrid bluegrass and KBG genotypes to heat and drought stress is important for the identification of stress tolerance mechanisms and developing breeding strategies to select more stress-tolerant cool-season grasses.

Therefore, the objectives of this study were to determine the relative improvement in hybrid bluegrass for more drought or heat tolerance and examine differential mechanisms of hybrid bluegrass and KBG tolerance to drought and heat stress.

\section{Materials and Methods}

Plant materials and growth conditions. The plant material used for the experiment included: one third-generation $\left(\mathrm{BC}_{3}\right)$ backcross hybrid, 'BDF', one fourth-generation $\left(\mathrm{BC}_{4}\right)$ backcross hybrid (' 845 ') (a cross between BDF and 'Midnight'), and two KBG genotypes ('C-74' and 'Midnight'). 'Midnight' had better drought tolerance than 'C-74' (Abraham et al., 2004). Plants of both hybrids and KBG genotypes were collected from 3-year-old field plots in the turfgrass farm at Rutgers University, New Brunswick, $\mathrm{NJ}$, and transplanted into polyvinyl chloride (PVC) tubes filled with a sterilized mixture of 1:3 (by volume) sand and sandy loam soil (fine-loamy, mixed mesic Typic Hapludult). Split PVC tubes consisted of three sections (each $10 \mathrm{~cm}$ in diameter $\times 20 \mathrm{~cm}$ long) connected together with duct tape for a total of 48 tubes. The bottom of the lower section for each tube was covered with nylon screen for drainage.

Plants were first grown in a greenhouse at Rutgers University for $\approx 60 \mathrm{~d}$, fertilized twice with controlled-release fertilizer (with $18 \%$ nitrogen, $4 \%$ phosphorus, and $8 \%$ potassium), and watered three times per week until drainage occurred from the bottoms of tubes at each irrigation. Turf was hand-clipped weekly at $\approx 5$-cm height. The tubes were then moved to growth chambers set at $22{ }^{\circ} \mathrm{C}$ day/ $18{ }^{\circ} \mathrm{C}$ night temperature, 14 -h photoperiod, and photosynthetically active radiation $(P A R)$ of 600 $\mu \mathrm{mol} \cdot \mathrm{m}^{-2} \cdot \mathrm{s}^{-1}$ ) and allowed to acclimate for $15 \mathrm{~d}$ before treatments were imposed.

Treatments and experimental design. The treatments included: 1) control: plants were grown under the optimum temperature conditions $\left(22{ }^{\circ} \mathrm{C}\right.$ day/ $18{ }^{\circ} \mathrm{C}$ night $)$ and maintained well watered by irrigating every other day; 2) drought stress: plants were exposed to $22{ }^{\circ} \mathrm{C}$ day $/ 18{ }^{\circ} \mathrm{C}$ night and not watered; and 3) heat stress: plants were subjected to $35^{\circ} \mathrm{C}$ day $/ 30{ }^{\circ} \mathrm{C}$ night and well watered. Each treatment was replicated in three growth chambers and treatments lasted for $35 \mathrm{~d}$. Six growth chambers were used simultaneously with three chambers for the control and drought treatment and three chambers for the heat stress treatment. The experiment consisted of two factors (four genotypes and three treatments) with three replications for each genotype or treatment in a split plot design with treatments as main plots and 
genotypes as subplots. Each replicate or pot contained multiple plants.

Measurements. Volumetric moisture content in the top $20 \mathrm{~cm}$ soil was measured using the time domain reflectometry (Soil Moisture Equipment, Inc., St. Barbara, CA). Turf quality (TQ) was rated weekly on a 1 to 9 scale, in which $1=$ brown, dead turf and $9=$ optimum color, density, and uniformity (Turgeon, 2002). A rating of 6 indicates minimum acceptable TQ for home lawns. Turf quality rating was used as a general indicator for drought or heat tolerance.

Leaf photochemical efficiency was determined weekly on three randomly selected groups (subsamples) of fully expanded leaves from each plant with a fluorescence induction monitor (Dynamax, Houston, TX). Leaves were dark-adapted in a leaf clip for $30 \mathrm{~min}$ before measurements were taken. Photochemical efficiency was expressed as chlorophyll fluorescence in the ratio of variable to maximum fluorescence $(\mathrm{Fv} / \mathrm{Fm})$.

Single-leaf photosynthetic rate $(\mathrm{Pn})$ and transpiration rate were measured with a portable gas exchange system (LI-6400; LICOR, Inc., Lincoln, NE). Three groups (subsamples) of four fully expanded leaves per plant were placed in a leaf chamber and allowed to equilibrate for $\approx 1 \mathrm{~min}$ before data were recorded. Gas exchange parameters were measured on individual intact leaves at a $P A R$ of $600 \mu \mathrm{mol} \cdot \mathrm{m}^{-2} \cdot \mathrm{s}^{-1}$ and temperature of $23{ }^{\circ} \mathrm{C}$. All the measurements were made at $14 \mathrm{~d}$ of treatments. Water use efficiency (WUE) was calculated as the ratio of Pn to transpiration rate.

At the end of the experimental period ( $35 \mathrm{~d}$ ), roots were harvested separately from each section ( 0 to 20,20 to 40 , and 40 to $60 \mathrm{~cm}$ ) of the container and washed free of soil. Roots were dried at $85{ }^{\circ} \mathrm{C}$ and dry weight was determined. Root viability was measured using the method of triphenyltetrazolium chloride (TTC) reduction as described by Joslin and Henderson (1984) and Knievel (1973). Subsamples of 1.5 to $3.0 \mathrm{~g}$ fresh roots from each soil depth were incubated in $20 \mathrm{~mL}$ of $0.6 \%$ TTC solution in $50 \mathrm{~mm}$ phosphate buffer $\left(\mathrm{pH} \mathrm{7.4)}\right.$ for $20 \mathrm{~h}$ at $30{ }^{\circ} \mathrm{C}$. Formazan, formed from the reduction of TTC by dehydrogenase enzymes in living tissues, was then extracted in $95 \%(\mathrm{v} / \mathrm{v})$ ethanol at $60^{\circ} \mathrm{C}$ for $4 \mathrm{~h}$. The absorbance of the extractants was read at $490 \mathrm{~nm}$ with a spectrophotometer (Spectronic Genesys Series; Spectronic Instruments Inc., Rochester, NY). The standard curve was made using different proportions of living and dead roots (killed in an autoclave) to calculate the percentage of living root, which was expressed as proportion of living root dry weight in the total root dry weight.

Statistical analysis. General linear models procedure was used for the analysis of variance (SAS Institute, Cary, NC). Variation was partitioned into treatments, genotypes, and duration of treatment (time) as main effects and corresponding interactions. The Fisher's protected least significance test at the $0.05 P$ level was used to detect the differences among means of genotypes and treatments.

\section{Results}

Under the control and heat stress conditions, soil water content in pots for both hybrids and KBG genotypes was maintained at an average of $25 \%$ during the entire study period. Soil water content declined to $20 \%$, $14 \%, 10 \%, 5 \%$, and $3 \%$ at $7,14,21,28$, and $35 \mathrm{~d}$ of drought stress, respectively, for both hybrids and KBG genotypes.

Under well-watered conditions, TQ was not significantly different between the two hybrids and KBG genotypes (Fig. 1A), indi- cating the turf-forming properties of the two hybrids were comparable to $\mathrm{KBG}$ under optimal conditions. During 21 to $35 \mathrm{~d}$ of drought stress, hybrid ' 845 ' and KBG 'Midnight' maintained the highest quality, whereas $\mathrm{KBG}$ 'C74' had the lowest quality and hybrid 'BDF' was intermediate (Fig. 1B). Under heat stress, both hybrids had significantly higher turf quality than KBG 'Midnight' and ' $\mathrm{C} 74$ ' after $21 \mathrm{~d}$ of heat stress and maintained their TQ above the minimal acceptable level (6.0) during the entire treatment period, whereas TQ of 'Midnight' and
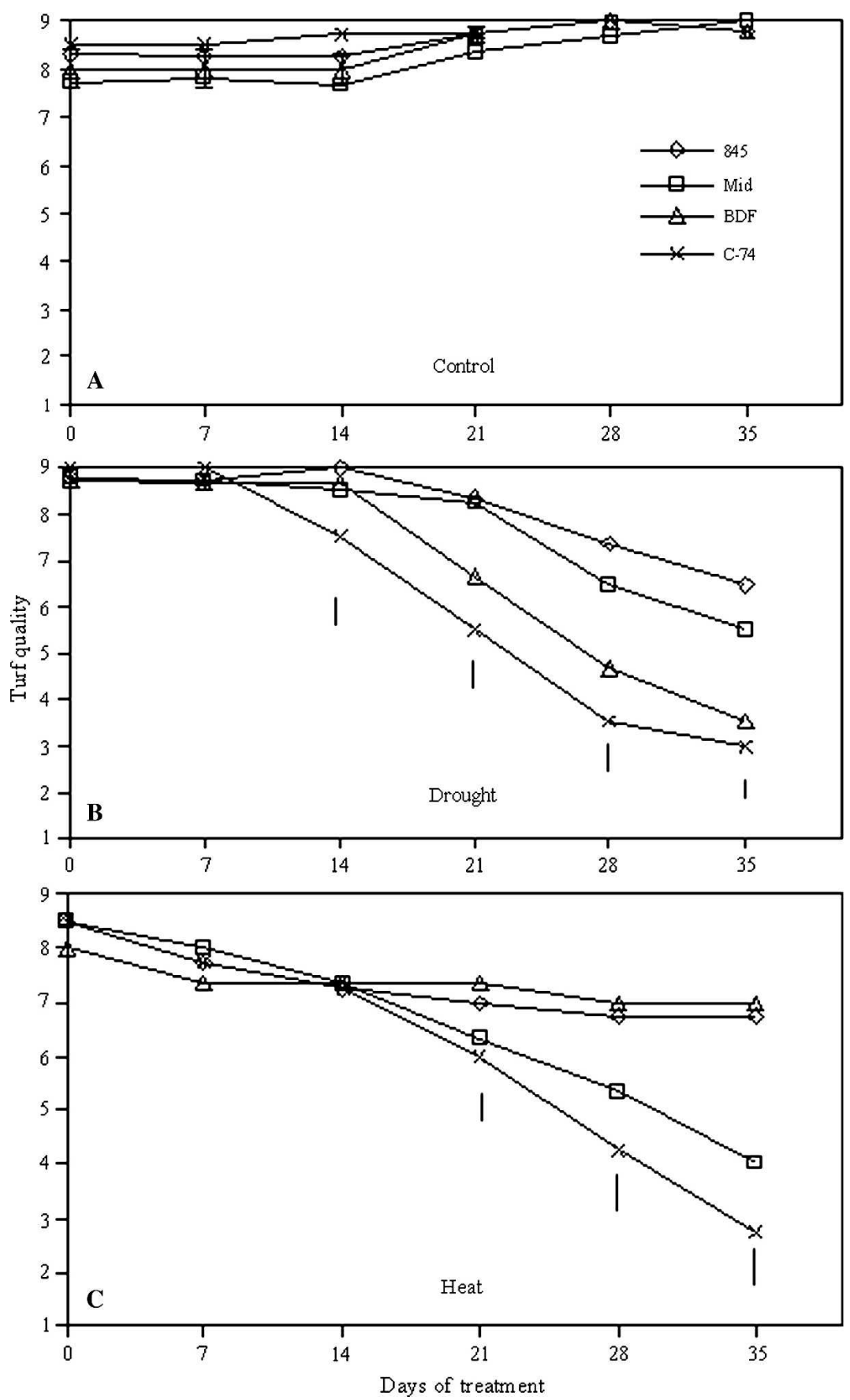

Fig. 1. Turf quality (1 to 9 visual scale, 9 indicating the best turf quality) of KBG ('Midnight' and 'C-74') and hybrid bluegrass ('BDF' and ' 845 ') under (A) optimum temperature and well-watered conditions (control), (B) drought stress (drought), and (C) heat stress (heat). Vertical bars indicate least significant different values $(P=0.05)$ for genotypes comparison at a given day of treatment. 
'C-74' dropped to below $6.0 \times 28 \mathrm{~d}$ of treatment (Fig. 1C).

Leaf photochemical efficiency did not exhibit variation between hybrids and $\mathrm{KBG}$ genotypes under well-watered conditions (Fig. 2A). A significantly higher Fv/Fm was found at 21 and $28 \mathrm{~d}$ of drought in hybrid ' 845 ' and at $28 \mathrm{~d}$ in 'hybrid 'BDF' and $\mathrm{KBG}$ 'Midnight' compared with KBG 'C-74' (Fig. 2B). After $21 \mathrm{~d}$ of heat stress, hybrid 'BDF' and ' 845 ' maintained significantly higher $\mathrm{Fv}$ / Fm compared with $\mathrm{KBG}$ 'Midnight' and ' $\mathrm{C}$ 74' (Fig. 2C).

No significant difference in leaf net Pn, transpiration rate, and WUE was found among the KBG genotypes and hybrids under the control conditions (Table 1). Under drought stress, Pn and transpiration rate of two KBG genotypes and both hybrids decreased below their respective control level, but hybrid '845' and 'BDF' and KBG 'Midnight' maintained a higher level of Pn and transpiration rate than 'C-74'; WUE of KBG 'Midnight' and hybrid 'BDF' and ' 845 ' did not change from the control level and was significantly higher than that for ' $\mathrm{C}-74$ ', which exhibited a significant decline (Table 1). Under heat stress, Pn and transpiration rate were maintained at the same level as the controls for both hybrids, but decreased significantly for both KBG genotypes, and all three parameters $(\mathrm{Pn}$, transpiration rate, and WUE) were significantly higher in the two hybrids than in the two KBG genotypes, except for hybrid ' 845 ', which was comparable in Pn to the two hybrids (Table 1).

Except for the hybrid ' 845 ', which was comparable to the control in root dry weight at the 0 to $20 \mathrm{~cm}$ under drought, root dry weight was reduced under both drought and heat stress for all the genotypes in all three soil layers, but to a greater extent under heat stress (Table 2). Generally, no significant differences in root dry weight were found in all three soil layers among KBG genotypes and hybrids under control conditions, except a lower value for $\mathrm{KBG}$ ' $\mathrm{C}-74$ ' at the 20 - to $40-\mathrm{cm}$ layer and a higher value for hybrid 'BDF' at the $40-$ to $60-\mathrm{cm}$ layer. Under drought stress, hybrid ' 845 ' had significantly more root mass in the upper 0 to $20 \mathrm{~cm}$ soil, hybrid 'BDF' had the most roots in the 40 to $60 \mathrm{~cm}$ soil layer, and $\mathrm{KBG}$ ' $\mathrm{C}-74$ ' had the lowest root dry weight in 0 to $20 \mathrm{~cm}$ and 20 to $40 \mathrm{~cm}$ layers compared with other three genotypes (Table 2). Under heat stress, hybrid 'BDF' had the most root mass in the 40 to $60 \mathrm{~cm}$ soil layer and KBG 'C-74' had the least amount of roots in all three layers, particularly the $40-$ to $60-\mathrm{cm}$ layer; both hybrids 'BDF' and ' 845 ' had significantly higher root dry weight than the two KBG genotypes at 40- to 60-cm depth (Table 2).

Root viability was not significantly different between hybrids and KBG genotypes in any soil layers under the control conditions (Fig. 3A). Under drought stress, KBG ' $\mathrm{C}-74$ ' had significantly lower root viability in the 0 to $20-\mathrm{cm}$ and $20-$ to $40-\mathrm{cm}$ layers than both hybrids and 'Midnight', whereas there were no significant differences among the geno-
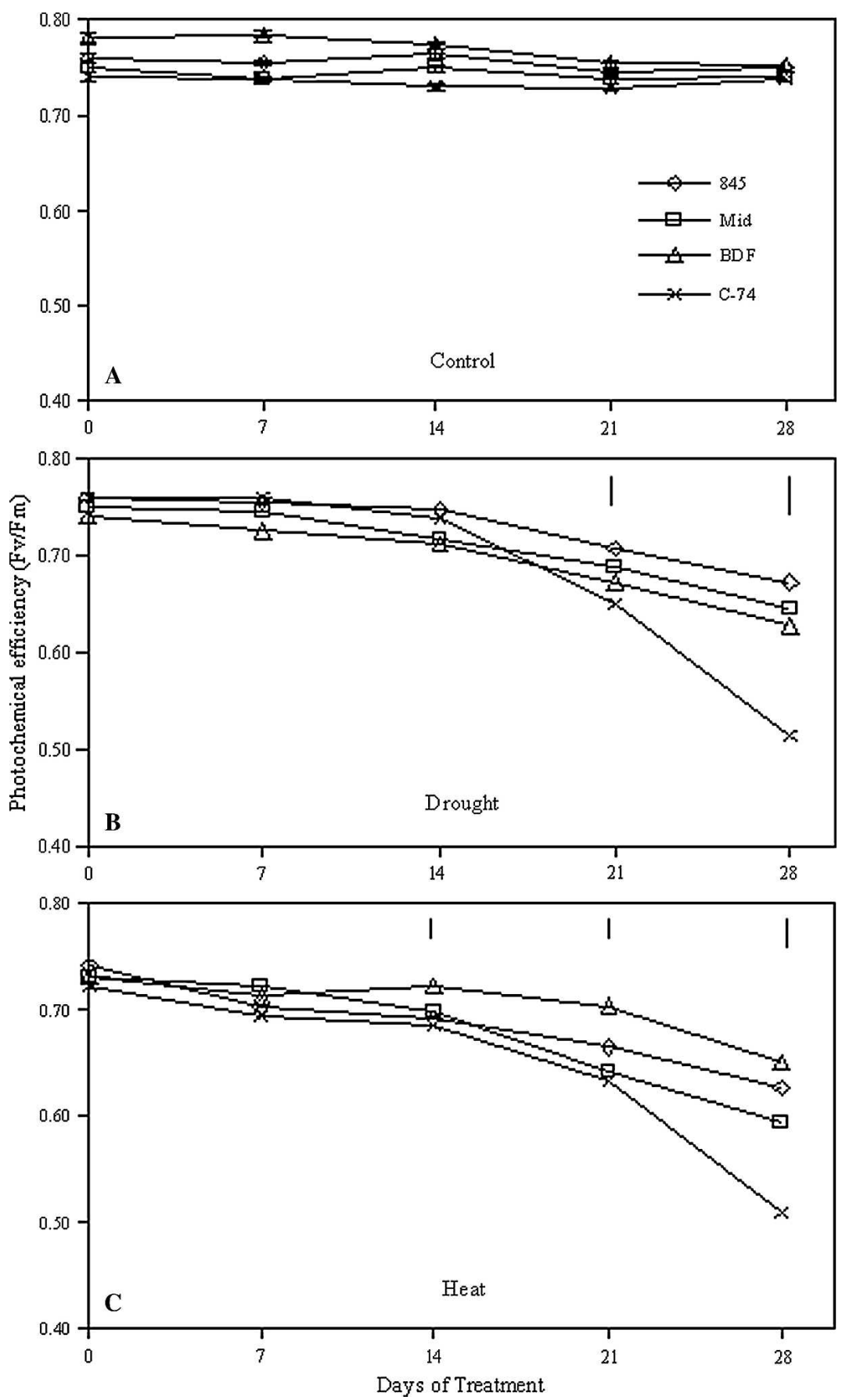

Fig. 2. Leaf photochemical efficiency ( $\mathrm{Fv} / \mathrm{Fm})$ of KBG ('Midnight' and 'C-74') and hybrid bluegrass ('BDF' and ' 845 ') under (A) optimum temperature and well-watered conditions (control), (B) drought stress (drought), and $(\mathbf{C})$ heat stress (heat). Vertical bars indicate least significant different values $(P=$ 0.05 ) for genotypes comparison at a given day of treatment.

types in the 40- to $60-\mathrm{cm}$ layer (Fig. 3B). Under heat stress, both hybrids maintained significantly higher root viability than the two KBG genotypes in 0- to 20- and 20- to 40 -cm layers, whereas no significant genotypic differences were detected in the 40- to 60-cm depth (Fig. 3C).

\section{Discussion}

In this study, both hybrids from Texas bluegrass backcrossed with Kentucky bluegrass for three generations ('BDF') or four generations ('845') exhibited similar turf quality, root growth, and physiological characteristics to both KBG genotypes under optimal temperature and well-watered conditions, suggesting that the two hybrid bluegrass genotypes had similar growth and physiological traits under optimal growth conditions. The main purpose of developing hybrid bluegrass was to transfer stress tolerance traits to Kentucky bluegrass with good TQ. Our study found that drought tolerance, evaluated as TQ, of the two hybrids was improved significantly compared with $\mathrm{KBG}$ 
Table 1. Leaf net photosynthetic rate (Pn), transpiration rate, and water use efficiency (WUE) for KBG ('Midnight' and 'C-74') and hybrid bluegrass ('BDF' and '845') under optimal temperature and wellwatered conditions (control), drought, and heat stress conditions ${ }^{\mathrm{z}}$.

\begin{tabular}{llccc}
\hline Treatment & Genotype & $\begin{array}{c}\text { Pn } \\
\left(\mu \mathrm{mol} \cdot \mathrm{m}^{-2} \cdot \mathrm{s}^{-1} \mathrm{CO}_{2}\right)\end{array}$ & $\begin{array}{c}\text { Transpiration } \\
\left(\mathrm{mol} \cdot \mathrm{m}^{-2} \cdot \mathrm{s}^{-1} \mathrm{H}_{2} \mathrm{O}\right)\end{array}$ & $\begin{array}{c}\text { WUE } \\
\left(\mathrm{CO}_{2} / \mathrm{H}_{2} \mathrm{O}\right)\end{array}$ \\
\hline Control & Midnight & $8.51 \mathrm{aA}^{\mathrm{y}}$ & $3.27 \mathrm{aA}$ & $2.60 \mathrm{aA}$ \\
& $\mathrm{C}-74$ & $8.62 \mathrm{aA}$ & $3.25 \mathrm{aA}$ & $2.65 \mathrm{aA}$ \\
& BDF & $9.20 \mathrm{aA}$ & $4.15 \mathrm{aA}$ & $2.22 \mathrm{aA}$ \\
Drought & 845 & $8.45 \mathrm{aA}$ & $3.24 \mathrm{aA}$ & $2.61 \mathrm{aA}$ \\
& Midnight & $4.75 \mathrm{bB}$ & $1.89 \mathrm{aB}$ & $2.51 \mathrm{aA}$ \\
& C-74 & $1.80 \mathrm{cC}$ & $0.97 \mathrm{bB}$ & $1.86 \mathrm{bB}$ \\
& BDF & $5.12 \mathrm{bB}$ & $1.95 \mathrm{aB}$ & $2.63 \mathrm{aA}$ \\
Heat & 845 & $6.34 \mathrm{aB}$ & $2.29 \mathrm{aB}$ & $2.77 \mathrm{aA}$ \\
& Midnight & $4.31 \mathrm{bB}$ & $2.42 \mathrm{bB}$ & $1.78 \mathrm{bB}$ \\
& C-74 & $4.27 \mathrm{bB}$ & $2.25 \mathrm{bB}$ & $1.89 \mathrm{bB}$ \\
& BDF & $8.38 \mathrm{aA}$ & $3.85 \mathrm{aA}$ & $2.17 \mathrm{aA}$ \\
& 845 & $6.98 \mathrm{bA}$ & $3.09 \mathrm{aA}$ & $2.26 \mathrm{aB}$ \\
\hline
\end{tabular}

${ }^{\mathrm{z}}$ Measurements were made at $14 \mathrm{~d}$ of treatments.

${ }^{\mathrm{y}}$ Means within the columns followed by different lowercase letters were significantly different based on least significant different test (LSD) $(P=0.05)$ for genotype comparison for a given treatment; means followed by different uppercase letters were significantly different based on LSD test $(P=0.05)$ for treatment comparison for a given genotype.

Table 2. Root dry weight of KBG ('Midnight' and 'C-74') and hybrid bluegrass ('BDF' and '845') in 0- to $20-\mathrm{cm}, 20-$ to $40-\mathrm{cm}$, and $40-$ to $60-\mathrm{cm}$ soil layers under optimal temperature and well-watered conditions (control), drought, and heat stress ${ }^{\mathrm{z}}$.

\begin{tabular}{|c|c|c|c|c|}
\hline \multirow[b]{2}{*}{ Treatment } & \multirow[b]{2}{*}{ Genotype } & \multicolumn{3}{|c|}{ Root dry wt (g) } \\
\hline & & 0 to $20 \mathrm{~cm}$ & 20 to $40 \mathrm{~cm}$ & 40 to $60 \mathrm{~cm}$ \\
\hline \multirow[t]{4}{*}{ Control } & Midnight & $0.93 \mathrm{aA}^{\mathrm{y}}$ & $0.74 \mathrm{aA}$ & $0.27 \mathrm{bA}$ \\
\hline & C-74 & $0.81 \mathrm{aA}$ & $0.48 \mathrm{bA}$ & $0.25 \mathrm{bA}$ \\
\hline & $\mathrm{BDF}$ & $0.92 \mathrm{aA}$ & $0.75 \mathrm{aA}$ & $0.41 \mathrm{aA}$ \\
\hline & 845 & $1.05 \mathrm{aA}$ & $0.79 \mathrm{aA}$ & $0.24 \mathrm{bA}$ \\
\hline \multirow[t]{4}{*}{ Drought } & Midnight & $0.75 \mathrm{bB}$ & $0.54 \mathrm{aB}$ & $0.11 \mathrm{bB}$ \\
\hline & C-74 & $0.52 \mathrm{cB}$ & $0.37 \mathrm{bB}$ & $0.10 \mathrm{bB}$ \\
\hline & $\mathrm{BDF}$ & $0.65 \mathrm{bB}$ & $0.51 \mathrm{aB}$ & $0.30 \mathrm{aB}$ \\
\hline & 845 & $0.98 \mathrm{aA}$ & $0.60 \mathrm{aB}$ & $0.11 \mathrm{bB}$ \\
\hline \multirow[t]{4}{*}{ Heat } & Midnight & $0.31 \mathrm{abC}$ & $0.26 \mathrm{aC}$ & $0.10 \mathrm{cB}$ \\
\hline & C-74 & $0.27 \mathrm{bC}$ & $0.16 \mathrm{bC}$ & $0.06 \mathrm{cB}$ \\
\hline & $\mathrm{BDF}$ & $0.38 \mathrm{aC}$ & $0.30 \mathrm{aC}$ & $0.26 \mathrm{aB}$ \\
\hline & 845 & $0.34 \mathrm{abC}$ & $0.27 \mathrm{aC}$ & $0.15 \mathrm{bB}$ \\
\hline
\end{tabular}

${ }^{\mathrm{z}}$ Roots were harvested at $35 \mathrm{~d}$ of treatments.

${ }^{\mathrm{y}}$ Means within the columns followed by different lowercase letters were significantly different based on least significant different $(\mathrm{LSD})$ test $(P=0.05)$ for genotype comparison for a given treatment; means followed by different uppercase letters were significantly different based on LSD test $(P=0.05)$ for treatment comparison for a given genotype.

'C-74', but was comparable to 'Midnight', which is a relatively drought-tolerant KBG genotype (Abraham et al., 2004). Furthermore, both hybrids maintained significantly higher TQ than both KBG genotypes during prolonged periods of heat stress, suggesting that hybrid bluegrass had more improvement in heat tolerance relative to drought stress. Su et al. (2007) examined effects of heat and drought stress on a hybrid bluegrass, Kentucky bluegrass, and tall fescue and found that better turf performance of hybrid 'Thermal blue' under the combined drought and heat stress was mainly the result of its better heat tolerance compared with 'Apollo' Kentucky bluegrass and 'Dynasty' tall fescue. They, however, failed to identify mechanisms of improved heat tolerance. The physiological mechanisms for the improved stress tolerance in hybrid bluegrass were associated with photosynthesis, transpirational cooling, WUE, and root growth in our study, as discussed subsequently.

Inhibition of photosynthesis is one of the first responses in plants subjected to drought stress or heat stress, which may be associated with inhibition of photochemical reactions and/or carbon fixation (Berry and Björkman, 1980). Photochemistry of photosystem II, evaluated as chlorophyll fluorescence $(\mathrm{Fv} /$ Fm ratio), is particularly sensitive to heat stress (Georgieva and Yordanov, 1993). In the present study, both hybrids and droughttolerant KBG genotype 'Midnight' maintained higher single-leaf photochemical efficiency (Fv/Fm) and Pn compared with KBG 'C-74' under drought stress, and both hybrids had significantly higher $\mathrm{Fv} / \mathrm{Fm}$ and $\mathrm{Pn}$ than two KBG genotypes. These results suggest that improved stress tolerance, particularly heat tolerance, in hybrid bluegrass was associated with the improvement in both photochemical activities and carbon fixation capacity of individual leaves.

Plants may avoid dehydration by limiting water loss and maintaining water uptake (Hopkins, 1999). Under drought stress, both hybrids maintained higher transpiration rates and developed more extensive roots, especially at the deeper soil profile (40 to $60 \mathrm{~cm}$ ) for 'BDF' compared with $\mathrm{KBG}$ ' $\mathrm{C}-74$ ', suggesting that these hybrids were able to increase root uptake capacity by developing deep roots rather than controlling transpirational water loss to survive drought stress. These results were also observed by Bonos and Murphy (1999) for Kentucky bluegrasses grown in the field under summer stress conditions. Ebdon and Kopp (2004) suggested that low evapotranspiration rates may not always be correlated to better drought survival in Kentucky bluegrass, whereas deep rooting was closely associated with less leaf firing. In contrast to the effects of transpirational water loss for drought survival, transpiration cooling is beneficial for plants to avoid heat stress injury. Under heat stress, both hybrids had higher transpiration rate than both $\mathrm{KBG}$ genotypes. Correspondingly, both hybrids developed more extensive roots and maintained higher root viability within the upper 0 - to 20- and 20- to $40-\mathrm{cm}$ soil layers compared with the two KBG genotypes. It is well documented that developing extensive, viable root systems is positively correlated to water uptake and drought and heat tolerance in many species, including turfgrasses (Bonos and Murphy, 1999; Huang et al., 1997; Volaire and Lelievre, 2001). Our results indicate that the hybrids were able to better tolerate heat stress by maintaining active root growth, which may facilitate water uptake and, in turn, sustain transpirational cooling.

The maintenance of higher photosynthesis and transpiration in the hybrids, especially under heat stress, was reflected by the increases in WUE. WUE is commonly calculated from gas exchange measurements as the molar ratio of $\mathrm{CO}_{2}$ assimilated in photosynthesis to the amount of water lost through transpiration (Hopkins, 1999). Reduction in transpiration is the first line of defense against desiccation because it responds much quicker than the other morphological and physiological changes (Yordanov et al., 2000). In addition, reduction in transpiration (stomatal closing) may result in overaccumulation of $\mathrm{O}_{2}$ in cells and increase production of reactive oxygen species, which is toxic to photosynthetic systems. However, it also restricts the entry of $\mathrm{CO}_{2}$ to mesophyll cells and consequently reduces net photosynthetic rates (Yordanov et al., 2000). Both hybrids had significantly higher WUE than the two KBG genotypes exposed to heat stress, suggesting that the hybrids were able to maintain the balance between photosynthesis and transpiration, which can help plants to survive stress through efficient use of water without loss of the photosynthetic capacity. Ebdon and Kopp (2004) concluded that WUE was a useful selection criterion for superior performance of Kentucky bluegrass in water-limiting environments.

In conclusion, interspecific hybridization of Texas bluegrass and Kentucky bluegrass resulted in some improvement in drought and heat tolerance, particularly in comparison with KBG genotype 'C-74'. However, the 

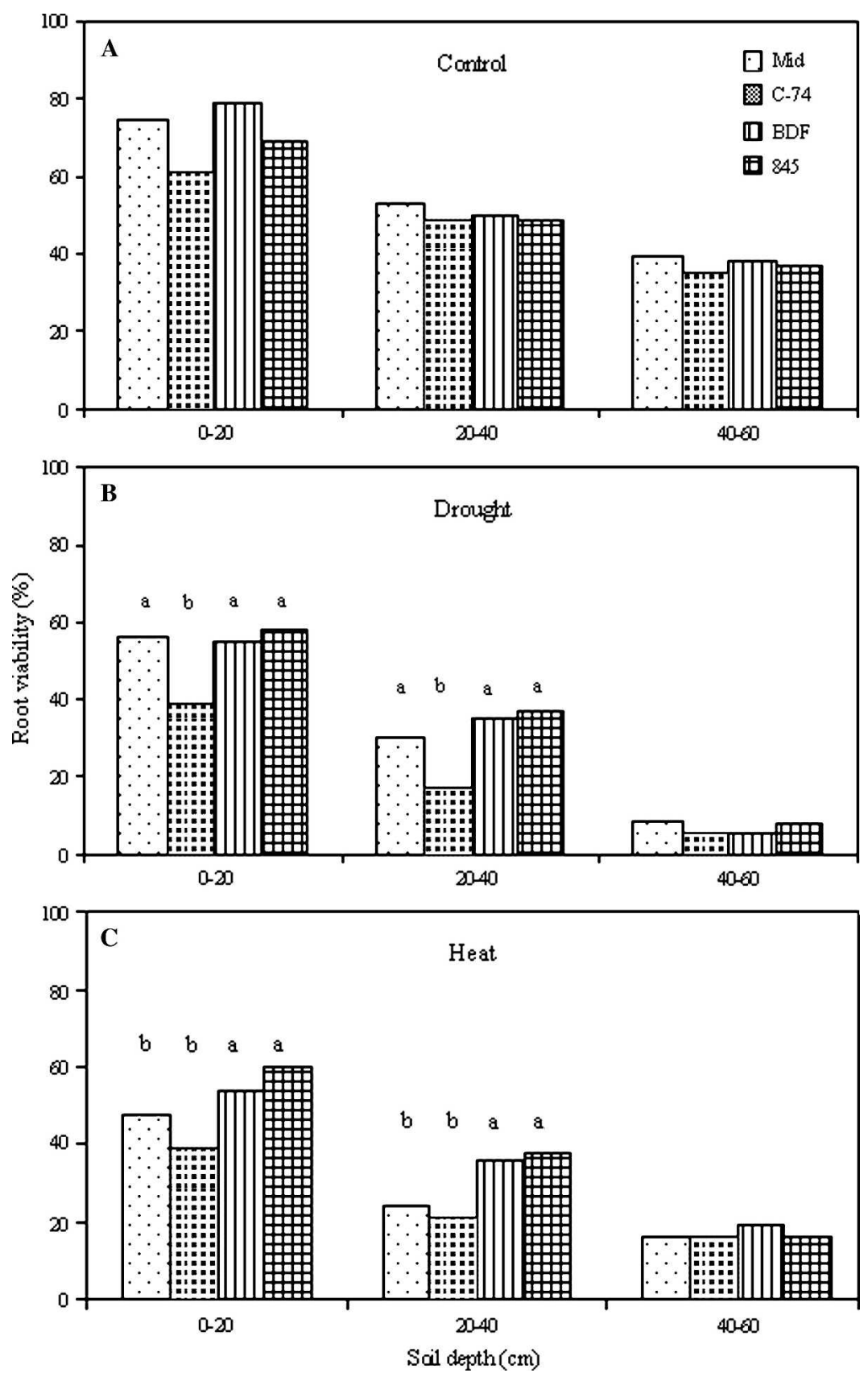

Fig. 3. Root viability of KBG ('Midnight' and 'C-74') and hybrid bluegrass ('BDF' and ' 845 ') in the 0 - to 20-cm, 20- to 40-cm, and 40- to 60-cm soil layers under (A) optimum temperature and well-watered conditions (control); (B) drought stress (drought); and (C) heat stress (heat). Columns with different letters for the same soil layer are significantly different based on least significant different test $(P=0.05)$.

degree of improvement was greater in terms of heat tolerance compared with drought tolerance. The drought resistance of the hybrids was closely related with the drought resistance of their male KBG parent 'Midnight'. The improved heat tolerance observed may have been mainly the result of the traits or genes transferred from Texas bluegrass through hybridization. The maintenance of higher photosynthetic capacity, transpiration, and WUE coupled with the development of an extensive, viable root system for the exploitation of a greater volume of soil moisture
Bonos, S.A., R.F. Bara, W.K. Dickson, D.A. Smith, M.M. Mohr, E. Watkins, J.A. Murphy, W.A. Meyer, and C.R. Funk. 2000. Performance of Kentucky bluegrass cultivars and selections in NJ turf trials. Rutgers Turfgrass Proc. 31:99-164.

Bonos, S.A. and J.A. Murphy. 1999. Growth responses and performance of Kentucky bluegrass under summer stress. Crop Sci. 39:770-774.

Ebdon, J.S. and K.L. Kopp. 2004. Relationship between water use efficiency, carbon isotope discrimination, and turf performance in genotypes of Kentucky bluegrass during drought. Crop Sci. 44:1754-1762.

Fry, J. and B. Huang. 2004. Irrigation, p. 153-192. In: Fry, J.D. and B. Huang (eds.). Applied turfgrass physiology and science. John Wiley \& Sons, Inc., Hoboken, NJ.

Georgieva, K. and I. Yordanov. 1993. Temperature dependence of chlorophyll fluorescence parameters of pea seedling. J. Plant Physiol. 142:151155.

Gould, F.W. 1975. The grasses of Texas. Texas A\&M Univ. Press, College Station, TX.

Hopkins, W.G. 1999. Introduction to plant physiology. 2nd Ed. John Wiley \& Sons, Inc., New York, NY.

Huang, B., R.R. Duncan, and R.N. Carrow. 1997. Drought-resistance mechanisms of seven warmseason turfgrasses under surface soil drying: II. Root aspects. Crop Sci. 37:1863-1869.

Jiang, Y. and B. Huang. 2000. Effects of drought or heat alone and in combination on Kentucky bluegrass. Crop Sci. 40:1358-1362.

Joslin, J.D. and G.S. Henderson. 1984. The determination of percentage of living tissue in woody fine root samples using triphenytetrazolium chloride. Forest Sci. 30:965-970.

Knievel, D.P. 1973. Procedure for estimating ratio of live to dead root dry matter in root core samples. Crop Sci. 13:124-126.

Meyer, W.A. and C.R. Funk. 1989. Progress and benefits to humanity from breeding cool-season grasses for turf, p. 31-48. In: Sleper, P.A., K.H. Asay, and J.F. Pedersen (eds.). Contributions from breeding forage and turf grasses. CSSA Spec. Publ. 15. CSSA, Madison, WI.

Qian, Y. and J.D. Fry. 1997. Water relations and drought tolerance of four turfgrasses. J. Amer. Soc. Hort. Sci. 122:129-133.

Read, J.C., J.A. Reinert, P.F. Colbaugh, and W.E. Knoop. 1999. Registration of 'Reveille' hybrid bluegrass. Crop Sci. 39:590.

Su, K., D.J. Bremer, S.J. Keeley, and J.D. Fry. 2007. Effects of high temperature and drought on hybrid bluegrass compared with Kentucky bluegrass and tall fescue. Crop Sci. 47:2152-2161.

Turgeon, A.J. 2002. Turfgrass management. 6th Ed. Prentice Hall, Englewood Cliffs, NJ.

United States Department of Agriculture. 1937. Breeding miscellaneous grasses. In: Vinall, H.N. and M.A. Hein (eds.). Yearbook of Agriculture 1937. USDA, U.S. Gov. Printing Office, Washington, DC.

Volaire, F. and F. Lelievre. 2001. Drought survival in Dactylis glomerata and Festuca arundinacea under similar rooting conditions in tubes. Plant Soil 229:225-234.

White, R.H., M.C. Engelke, S.J. Morton, and B.A. Ruemmele. 1992. Competitive turgor maintenance in tall fescue. Crop Sci. 32:251-256.

Abraham, E.M., B. Huang, S.A. Bonos, and W.A Meyer. 2004. Evaluation of drought resistance for Texas bluegrass, Kentucky bluegrass, and their hybrids. Crop Sci. 44:1746-1753.

Beard, J.B. 1973. Turfgrass: Science and culture. Prentice-Hall, Inc., Englewood Cliffs, NJ.

Berry, J. and O. Björkman. 1980. Photosynthetic response and adaptation to temperature in higher plants. Annu. Rev. Plant Physiol. 31:491-543.
Yordanov, I., V. Velikova, and T. Tsonev. 2000. Plant response to drought, acclimation, and stress tolerance. Photosynthetica 38:171-186.

Zhang, X. and R.E. Schmidt. 1999. Antioxidant responses to hormone-containing product in Kentucky bluegrass subjected to drought. Crop Sci. 39:545-551. 